\section{The APSA Graduate Fellowship Program}

In 1969, the American Political Science Association authorized the establishment of the Minority Graduate Fellowship Program. It was created in response to a recommendation by the APSA Committee on the Status of Blacks in the Profession. The Committee recognized a need to overcome obstacles that hampered the recruitment of minorities for higher education, such as financial difficulties and the limited information among graduate departments about prospective minority students. Thus, the purpose of the APSA Graduate Fellowship Program is to:

- Identify and aid prospective minority students who are pursuing a Ph.D. in political science

- Encourage other institutions to provide financial assistance to these students

- Contribute to the development of political science by recruiting students who will bring greater diversity to the field.

The first African American fellows were selected for the 1970-71 academic year, and in 1984 the Council established the same program for Latinos. The first fellow to receive his doctorate was Donald Tryman, who graduated from Florida State University in 1975. Currently, over fifty African Americans and thirty Latinos are enrolled in graduate programs of political science, and the number of doctorates among minorities steadily increases.

Following are the fellows who have received their doctorate or who have completed all requirements except their dissertation.

\footnotetext{
African Americans

Yvette Alex, Ph.D., Ohio State James Ammons, Ph.D., Florida State

Richard Braggs, Ph.D., Howard Jerrie Brown, A.B.D., South Carolina

Joseph Brown, Ph.D., Purdue Michael Combs, Ph.D., Washington University Rodney Cunningham, A.B.D., Syracuse$$
\text { James Duncan, A.B.D., Howard }
$$

Carolyn Currie Eaglin, A.B.D., J.D., SUNY-Buffalo James Eaglin, A.B.D., J.D., SUNY-Buffalo

Earnest Lee Easton, Ph.D., Cornell

Kathy S. Golden, Ph.D., Kentucky

Earl Green, Jr., Ph.D., New

York

Michael Hanchard, Ph.D., Princeton

Sheila Harmon-Martin, A.B.D., Clark-Atlanta

Luke Harris, A.B.D., Princeton

Ronando Holland, Ph.D., Duke

Bryan O. Jackson, Ph.D., Michigan

Joy Ann James, Ph.D., Fordham

Ollie A. Johnson, A.B.D., U.C.

Berkeley

Murel Jones, Ph.D., Howard

Augustus Jones, Ph.D., Washing-

ton University

Francis Kilonzo, Ph.D., Claremont

Walter Mebane, Ph.D., Yale

Barry Morris, A.B.D., Emory

Zelma Mosley, Ph.D., Wisconsin, Milwaukee

Larry Moss, Ph.D., Atlanta

Anthony Neal, Ph.D., Atlanta

Roger Oden, Ph.D., Chicago

Marion Orr, Ph.D., Maryland

Desiree Pedescleaux, Ph.D.,

Yale

Gail Peek, Ph.D., Princeton

Georgia Persons, Ph.D., MIT

Freeman Pollard, Ph.D., Indiana

Adolph Reed, Ph.D., Atlanta

Pearl T. Robinson, Ph.D., Co-

lumbia

Jocelyn Sargent, A.B.D., Michigan

Keith Simmons, Ph.D., Illinois

Reginald Simmons, Ph.D.,

Howard

Nellie Sinbad, Ph.D., Yale

R. Drew Smith, Ph.D., Yale

Thomas Stewart, A.B.D., Harvard

Carol Swain, Ph.D., North Carolina

Duane Taylor, Ph.D., Brandeis

Edward Thompson, Ph.D.,

Howard

Donald Tryman, Ph.D., Florida

State

Shirley Washington, Ph.D.,

Howard

Jacqueline Washington, Ph.D., Howard
Hilbourne A. Watson, Ph.D.,

Howard

Freida Wheaton, A.B.D., J.D.,

Washington University

Larry White, Ph.D., Yale

Ernest Wilson, Ph.D., UC-Berkeley

\section{Latinos}

Gilbert Arroya, A.B.D., Purdue

Anthony Desales Affigne, Ph.D.,

Brown University

Jo Ellyn Fountain, A.B.D.,

North Carolina

Carlos Juarez, A.B.D., UCLA

Cecilia Rodriguez, Ph.D., Uni-

versity of Dallas

Diana Saco, A.B.D., Minnesota

\section{Section News}

The organized section on Transformational Politics is holding a regional meeting at Yale University on Saturday, April 2, 1994, from 10:30 a.m. to 4:30 p.m. The theme of the meeting is "Crossing the Border: Theory into Practice." Papers will be presented by Barbara Knoll (Massachusetts Institute of Technology), Doug Bond (Harvard University), and Art Stein (University of Rhode Island). The paper presenters and conference participants will discuss the thesis that there is a false distinction between theory and practice.

The Transformational Politics section welcomes nonmembers as well as members. To obtain further information about the meeting, to register, and to receive advance copies of the papers to be delivered, contact Alexander Ulavov, 70 Howe Street, Apt. 211, New Haven, CT 06511; Phone: (203) 6242242; Fax: Department of Classics, Yale University (203) 432-1079.

President Elaine Sharp of the Urban Politics Section has appointed 1994 Nominating Committee, which is charged with submitting a slate at the annual business meeting during the APSA convention. The Committee must submit six nominees for two-year terms on the Executive Council and one nominee for president-elect, who will serve one year before assuming the presidency at the end of the 1995 annual business meeting. 